\title{
Microwave Pretreatment for Thiourea Leaching for Gold Concentrate
}

\author{
Nag-Choul Choi ${ }^{1, \dagger}$, Bong-Ju Kim ${ }^{2,+}$, Kanghee Cho ${ }^{1}$, Soonjae Lee ${ }^{2, *}$ (i) and \\ Cheon-Young Park ${ }^{3, *}$ \\ 1 Department of Rural Systems Engineering/Research Institute of Agriculture and Life Sciences, \\ Seoul National University, Seoul 08826, Korea; nagchoul@empas.com (N.-C.C.); \\ kanghee1226@hanmail.net (K.C.) \\ 2 Department of Earth and Environmental Sciences, Korea University, Seoul 02841, Korea; \\ nega6495@hanmail.net \\ 3 Department of Energy and Resource Engineering, Chosun University, Gwangju 61452, Korea \\ * Correspondence: soonjam@korea.ac.kr (S.L.); cybpark@chosun.ac.kr (C.-Y.P.); \\ Tel.: +82-2-3290-3177 (S.L.); +82-62-230-7878 (C.-Y.P.) \\ + These authors contributed equally.
}

Received: 4 September 2017; Accepted: 27 September 2017; Published: 1 October 2017

\begin{abstract}
In this research, we studied the use of microwave pretreatment to enhance the efficiency of Au leaching from gold concentrate. The gold concentrate was pretreated using microwaves with different irradiation time. The sample temperature was increased up to $950{ }^{\circ} \mathrm{C}$ by the microwave irradiation. A scanning electron microscope-energy dispersive spectrometer showed the evolution of microcracks and the reduction of sulfur on the mineral surface. X-ray diffraction data also showed the mineral phase shift from pyrite to hematite or pyrrhotite. A leaching test was conducted for the microwave-treated and untreated gold concentrates using thiourea. Although the thiourea leaching recovered $80 \%$ of $\mathrm{Au}$ from the untreated concentrate, from the treated concentration, the Au could be recovered completely. Au leaching efficiency increased as the microwave irradiation time increased, as well as with a higher composition of thiourea.
\end{abstract}

Keywords: microwave; pyrite; thiourea leaching; gold

\section{Introduction}

For the efficient recovery of gold from ore, cyanidation has been widely used in extractive metallurgy for the past 100 years. Recently, considerable attention on non-cyanide lixiviants has been arisen in the metallurgical industry due to the increasing environmental concerns over cyanidation $[1,2]$.

Thiourea, one of the alternative lixiviants, has been recognized as a potentially viable lixiviant. It can generate relatively strong gold complexes and promptly leach gold ores when catalyzed by ferric ions, and it is eco-friendly due to its low toxicity [3,4]. However, there are ores that are not amenable to treat by cyanide and thiourea, such as pyrites. Inside pyrite, for example, a considerable amount of Au exists as a refractory and invisible state. In order to recover Au from such a concentrate, it is important to decompose pyrites $[5,6]$.

A roasting process using electric furnaces and high-pressure oxidation has been used to decompose pyrites in Au concentrates. However, the roasting process is uneconomical and involves environmental problems $[7,8]$. A microwave process has been reported as an alternative for the roasting process. It has many advantages, such as being selective to specific substances, using a non-contact method from the energy source, rapid and uniform energy transfer, and convenient operation in terms of generation source manipulation $[9,10]$. 
Previous studies have reported on the microwave treatment for various minerals. Uslu et al. [10] conducted research on the desulfurization of coals using microwaves. Huang and Rowson [11] treated pure pyrite and marcasite using microwaves in a mid-temperature $\left(50{ }^{\circ} \mathrm{C}\right)$ nitric acid solution. Ma et al. [12] studied the microwave treatment for the removal of sulfur and arsenic in Au concentrate. Amankwah and Pickles [13] reported the use of microwaves as a pretreatment process for gold recovery from carbonaceous sulfide concentrate by cyanide leaching. However, few studies have explained the relationship between the microwave irradiation and the enhancing leaching efficiency of Au from the gold concentrate.

In this research, we investigated the effect of microwave pretreatment on the recovery of gold from the gold concentrate by thiourea leaching. Alteration of the mineral phase was analyzed by comparing scanning electron microscope-energy dispersive spectrometer and X-ray diffraction data before and after the microwave treatment. Leaching experiments were conducted for the gold concentrates with and without microwave treatment.

\section{Materials and Methods}

\subsection{Gold Concentrates}

The gold concentrate $(38-45 \mu \mathrm{m})$ was obtained through the flotation process from an operating gold mine (Haenam, Korea). Mineral composition of the gold concentrate was analyzed using X-ray diffraction (X'Pert Pro MRD, PANalytical, Almelo, The Netherlands). To determine the chemical composition of the concentrate, the sample was digested with aqua regia. The solution chemistry was analyzed using atomic absorption spectrophotometers (AA-7000, Shimadzu, Kyoto, Japan). The sulfur contents on the concentrate was determined using a carbon-sulfur analyzer (CS-800, Eltra, Haan, Germany).

\subsection{Pretreatment of Gold Concentrate Using Microwaves}

Gold concentrate $(50 \mathrm{~g})$ was placed in a $1 \mathrm{~L}$ open vessel ceramic container. To measure the temperature of the sample, type $\mathrm{K}$ thermocouple was buried $5 \mathrm{~mm}$ beneath the surface of the concentrate sample [14-20]. The concentrates were microwave-irradiated with a variable power (maximum output $1000 \mathrm{~W}$ ) and a $2.45 \mathrm{GHz}$ kitchen type microwave oven was used for microwave heating for 10, 30, 50, and $70 \mathrm{~min}$. The weight of the sample was measured after microwave treatment. X-ray diffraction (XRD) and scanning electron microscope-energy dispersive spectrometer (SEM-EDS; S4800, Hitachi, Tokyo, Japan) analyses were conducted to observe the change in the mineral phase. The chemical composition of the sample was analyzed through aqua regia digestion, and atomic absorption spectrophotometers (AAS).

\subsection{Kinetic Au Leaching Experiments}

$\mathrm{Au}$ leaching experiments were conducted for the microwave-treated and untreated concentrates using various lixiviants with different composition. Experimental conditions are presented in Table 1. Lixiviants were prepared in a $250 \mathrm{~mL}$ flask by mixing $100 \mathrm{~mL}$ of thiourea solvents $(36.4-52.0 \mathrm{mM}) \mathrm{with}$ $0.6 \mathrm{~g}$ of additional solvent (sodium sulfate) and $3.5 \mathrm{~g}$ of oxidant (ferric sulfate). Prepared lixiviant has $\mathrm{pH}$ 1.3. Because sulfur in Au concentrates inhibits $\mathrm{Au}$ leaching, we used the additives, such as $\mathrm{SO}_{2}, \mathrm{Na}_{2} \mathrm{SO}_{3}$, or $\mathrm{Na}_{2} \mathrm{~S}_{2} \mathrm{O}_{5}$, and oxidants, such as $\mathrm{H}_{2} \mathrm{O}_{2}$ or $\mathrm{Fe}_{2}\left(\mathrm{SO}_{4}\right)_{3}$, to improve the rate of $\mathrm{Au}$ leaching [5,21-24].

The concentrates $(10 \mathrm{~g})$ were added to the lixiviant. The sample was agitated at $70{ }^{\circ} \mathrm{C}$ for $1 \mathrm{~h}$ using a mechanical stirrer with $120 \mathrm{rpm}$. Supernatants were withdrawn every $10 \mathrm{~min}$. The dissolved gold in the solution was measured using AAS. The rate of Au leaching was determined by following equation [25]:

$$
E=E_{I}\left(1-e^{-k t}\right)
$$


where $E(\%)$ is the $\mathrm{Au}$ concentration in the leaching solution at time $t, E_{I}(\%)$ is the maximum concentration of $\mathrm{Au}$, and $k\left(\mathrm{~min}^{-1}\right)$ is the leaching rate constant.

Table 1. Experimental conditions of microwave pretreatment and thiourea leaching.

\begin{tabular}{ccccc}
\hline \multirow{2}{*}{ Experiment } & \multirow{2}{*}{ Irradiation Time (min) } & \multicolumn{3}{c}{ Lixiviant (mM) } \\
\cline { 3 - 5 } & & Thiourea & Sodium Sulfate & Ferric Sulfate \\
\hline A & - & 34.7 & & \\
B & 10 & 34.7 & & \\
C & 30 & 34.7 & & \\
D & 50 & 34.7 & 0.6 & \\
E & 70 & 34.7 & & \\
F & 70 & 43.4 & & \\
G & 70 & 52.0 & & \\
\hline
\end{tabular}

\section{Result and Discussion}

\subsection{Effect of Microwave Irradiation on Gold Concentrate}

The gold concentration was irradiated with microwaves for 10, 30, 50, and $70 \mathrm{~min}$. As the irradiation time increased, sample temperature increased with non-linearity (Figure 1a). The sample temperature was rapidly increased for the first $10 \mathrm{~min}$, and the rate became lower after that. In the early irradiation time, the temperature increased with the rate of $1.12{ }^{\circ} \mathrm{C} \cdot \mathrm{s}^{-1} \mathrm{By}$ the microwave treatment, mass of the gold concentrate was reduced significantly (Figure 1b).
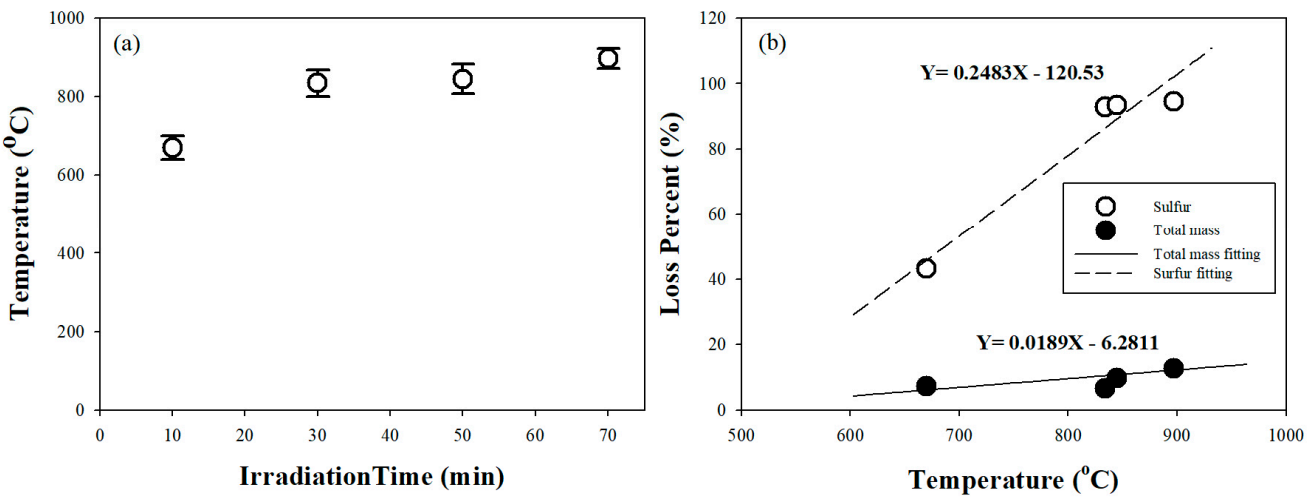

Figure 1. (a) Sample temperature, and (b) loss of the sample mass and the sulfur contents during the microwave irradiation.

Table 2 presents the chemical composition of the gold concentrates treated with microwaves. By the microwave irradiation, the sulfur contents were reduced significantly from the concentrate. Particularly in the early irradiation time, as the temperature increase to $670{ }^{\circ} \mathrm{C}$, the samples showed significant reduction in the sample mass as well as the sulfur content (Figure 1b). Further microwave irradiation resulted in further mass loss and the depletion of sulfur in the concentrates, so that the microwaves for $30 \mathrm{~min}$ achieved approximately $94.43 \%$ reduction in sulfur content. From 10 to $70 \mathrm{~min}$, the percent loss of the total mass and the sulfur content increased almost linearly as the temperature increased. The weight loss could be fitted with $y=0.0189 x-6.2811$, and the sulfur loss with $y=0.2483 x-120.53$. The ratio of the two slopes $(0.0189 / 0.2483=0.076)$ was less than the sulfur content of the raw concentrate (0.20), which indicates that other substances such as water and solvent were also removed during the microwave heating. The intercept of trend lines shows that the removal of weight and sulfur started around $332{ }^{\circ} \mathrm{C}$ and $485^{\circ} \mathrm{C}$, respectively. 
Table 2. Chemical composition of gold concentrates after the microwave treatment with different irradiation times.

\begin{tabular}{cccccccccc}
\hline \multirow{2}{*}{ Irradiation Time (min) } & \multicolumn{10}{c}{ Elements $(\mathbf{m g} / \mathbf{k g})$} \\
\cline { 2 - 10 } & $\mathbf{S i}$ & $\mathbf{F e}$ & $\mathbf{C u}$ & $\mathbf{Z n}$ & $\mathbf{P b}$ & $\mathbf{C o}$ & $\mathbf{S}$ & $\mathbf{A g}$ & $\mathbf{A u}$ \\
\hline Raw & 10,460 & 40,560 & 290 & 140 & 4550 & 2550 & 20,140 & 1026 & 133 \\
10 & 10,412 & 40,588 & 296 & 152 & 4566 & 2245 & 11,454 & 1022 & 139 \\
30 & 10,388 & 41,356 & 291 & 144 & 4597 & 2188 & 1445 & 1012 & 150 \\
50 & 10,401 & 41,599 & 284 & 143 & 4603 & 1384 & 1322 & 996 & 152 \\
70 & 10,122 & 42,560 & 277 & 138 & 4612 & 1355 & 1120 & 999 & 159 \\
\hline \multicolumn{10}{c}{ * measured using a carbon sulfur analyzer. }
\end{tabular}

The increase in the sample temperature by the microwave irradiation is due to high absorption of microwave energy by the sulfide minerals, such as pyrites, in the gold concentrate. McGill et al. [26] reported that the temperature of pyrites was increased to $1019{ }^{\circ} \mathrm{C}$ by exposure to microwaves for $6.75 \mathrm{~min}$ with $2.5^{\circ} \mathrm{C} \cdot \mathrm{s}^{-1}$ of temperature increasing rate. Huang and Rowson [11] reported that the temperature of pyrites $(0-63 \mu \mathrm{m})$ was increased at a rate of $7.5^{\circ} \mathrm{C} \cdot \mathrm{s}^{-1}$ by microwave irradiation for a shorter time period (40 s) [26]. The temperature was not increased continuously by long-term microwave irradiation. The maximum temperature of the minerals (pyrite) did not change significantly in our experiments. In the case of the inorganic material, the dielectric loss rate and the absorption rate were determined even when the material was microwave-irradiated for a long time [27].

The rapid removal of sulfur for the first $10 \mathrm{~min}$ is because of the destruction of the mineral structure by microwave irradiation. We can see that almost all the of sulfur was already reduced from the concentrate at $30 \mathrm{~min}$. The reduction in the sample weight due to an increase in microwave irradiation time was due to pyrites that absorbed microwave energy and were thermally decomposed so that $S$ was volatilized to become $\mathrm{SO}_{2}$, and subsequently be removed [11]. Haque [15] reported that pyrites emitted sulfur fumes as they generated pyrrhotite when irradiated by microwaves for $3-5 \min$ at $2450 \mathrm{MHz}$ and $30 \mathrm{~W}$.

\subsection{Mineralogical Change in Gold Concentrate by Microwave Irradiation}

To study the mineralogical alteration of gold concentrates by microwave irradiation, XRD analysis was conducted for microwave-treated gold concentrates, and it compared with raw gold concentrate (Figure 2). The diffraction lines showed that the raw concentrate was mainly composed of pyrites and quartz (Figure 2a). However, the gold concentrates treated with microwaves for 10 min showed the diffraction lines of hematite and pyrrhotite as well as those of quartz and pyrite (Figure $2 b$ ). The pretreated sample also revealed a significant reduction in the intensity of diffraction lines of pyrite compared to concentrate samples without irradiation. This is because pyrite is a hyperactive mineral that absorbs microwaves well, while quartz is a mineral that is transparent to microwaves, so that only pyrite reacted with microwaves and thermally decomposed selectively. The occurrence of the diffraction lines of hematite and pyrrhotite in the pretreated sample after microwave irradiation suggests the mineral phase of pyrite was changed into that of hematite and pyrrhotite $[9,13,28]$. Mineralogical phase change of pyrite is possible at $750{ }^{\circ} \mathrm{C}[11,29-31]$.

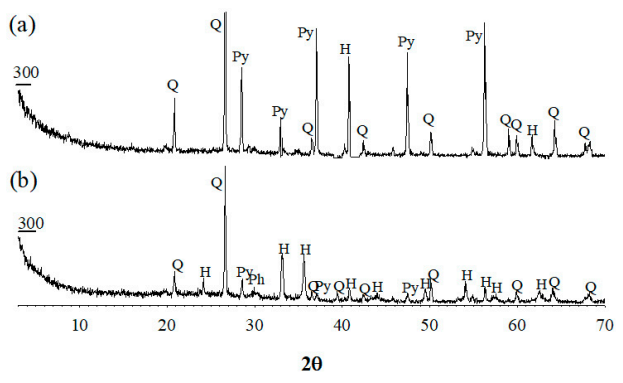

Figure 2. X-ray diffraction (XRD) patterns for the gold concentrates (a) before and (b) after microwave irradiation for $10 \mathrm{~min}$ (H: hematite; Py: pyrite; Ph: pyrrhotite; Q: quartz). 
Figure 3 presents the SEM-EDS analysis for raw and microwave-treated samples. Idiomorphic cubic pyrites were observed (Figure 3a). EDS analysis on the surface of the pyrites showed that the ratio of $\mathrm{Fe}$ and $\mathrm{S}$ was about 1:2 (at \%). Figure $3 \mathrm{~b}$ showed that the microwave irradiation developed microcracks on pyrite surface, so that the phase of the pyrites was changed to a porous phase. The EDS analysis showed that sulfur atoms on the pyrite surface were replaced by oxygen completely. The reduction in $\mathrm{S}$ and occurrence of $\mathrm{O}$ after the microwave irradiation was due to the occurrence of thermal stress, thermal decomposition, and oxidation in the pyrites simultaneously due to microwave heating [15]. Since microwaves selectively react to specific sulfur minerals, thermal stress occurs at the boundary between gangue and sulfur minerals [32,33], and this thermal stress incurs microcracks at the boundary of minerals whose thermal expansion coefficient is different from each other, or inside the minerals [28]. Very high temperature obtained in the boundaries could also produce thermal fracturing [34,35]. The generated microcracks and faults are ultimately followed by thermal fracturing, and this thermal fracturing degrades the strength of the sulfur minerals, thereby facilitating the crushing and milling of ore minerals, resulting in increased Au liberation efficiency from Au concentrates [32,33].
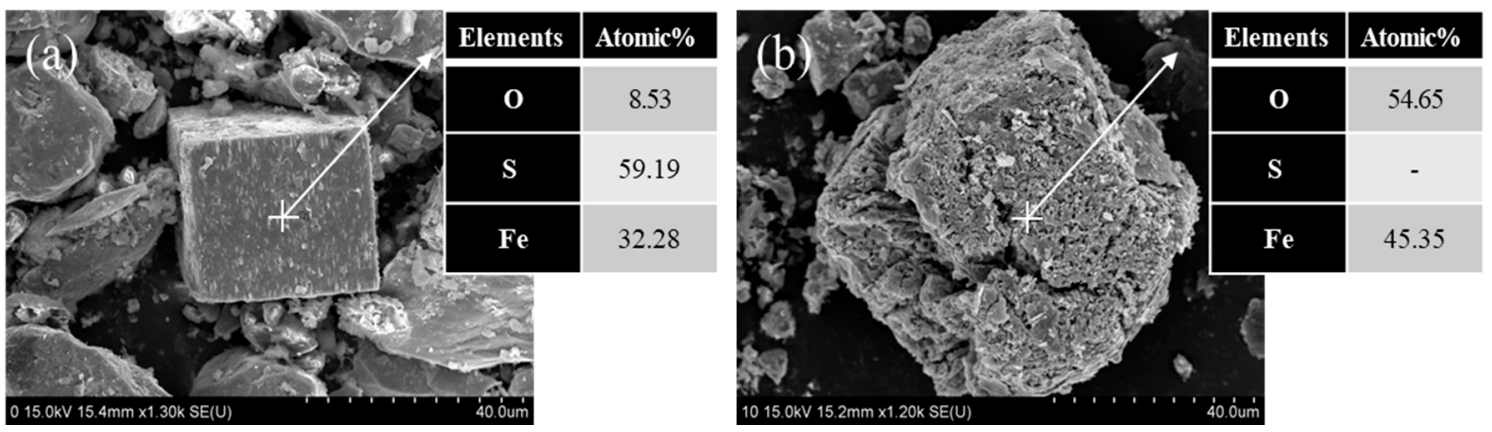

Figure 3. Scanning electron microscope-energy dispersive spectrometer (SEM-EDS) results for pyrite on microwave irradiation time with (a) $0 \mathrm{~min}$, (b) $10 \mathrm{~min}$.

\subsection{Gold Leaching}

\subsubsection{Effect of Microwave Irradiation on Au Leaching Efficiency}

Thiourea leaching experiments for gold recovery were conducted for gold concentrates microwave-treated for different irradiation times (Figure 4a). The results showed that the microwave treatment enhanced the rate of $\mathrm{Au}$ leaching. Without microwave treatment (Experiment $\mathrm{A}$ ), the $\mathrm{Au}$ leaching rate was about $78.1 \%$ after $60 \mathrm{~min}$ of the leaching experiment, whereas the Au leaching rate was about $95.5 \%$ after $50 \mathrm{~min}$ (Experiment D). In particular, the Au leaching rate reached $100 \%$ after an irradiation time of $70 \mathrm{~min}$ (Experiment E). Microwave treatment resulted in differential thermal expansion within the ore as a result of the varying loss factors of the constituents in the gold concentrate. In addition, these treatments may create high temperature internal gas phases, which lead to structural distortion and breakdown of the ore [36]. Since thiourea used as the Au solvent in this study can dissolve Au faster and had lower toxicity than cyanide, it has been used as an alternative solvent to cyanide $[37,38]$. 

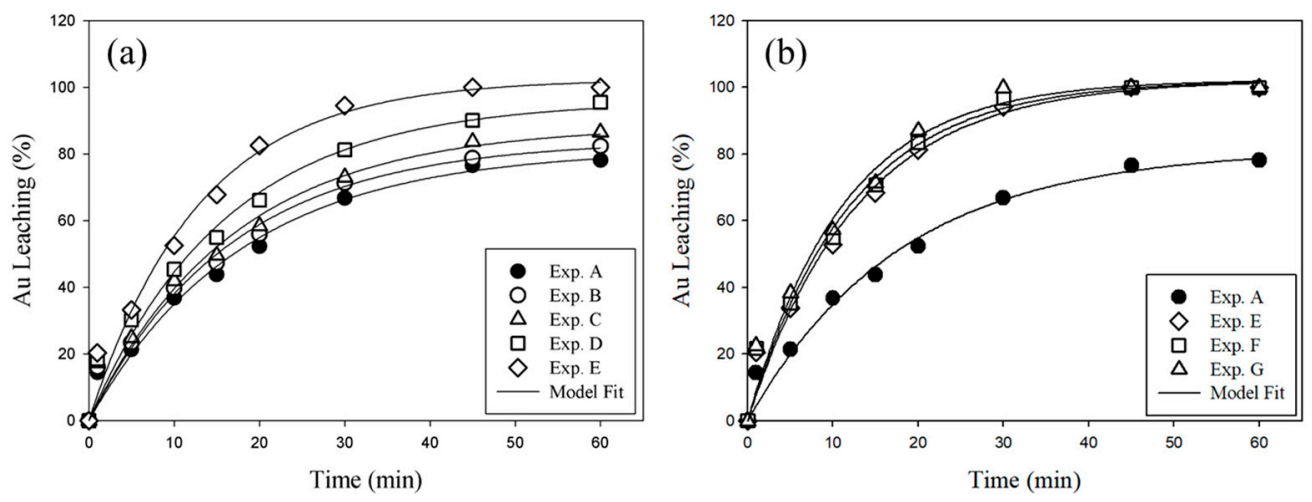

Figure 4. Gold recovery by leaching test under various conditions of (a) microwave pretreatment-irradiation time from 0 to $70 \mathrm{~min}$ and (b) lixiviant composition-thiourea concentration from 34.7 to $52.0 \mathrm{mM}$.

\subsubsection{Effect of Thiourea Concentration on Au Leaching Efficiency}

Lixiviants with different concentrations of thiourea were used for gold leaching from the samples that were microwave-treated for $70 \mathrm{~min}$. The result showed that as the concentration of thiourea increased, the Au leaching rate increased (Figure $4 \mathrm{~b}$ ). Based on the experimental results, the leaching parameters of the leaching experiment conditions estimated using Equation (1) are presented in Table 3. The maximum leaching percent of $\mathrm{Au}$ according to an increase in concentration of thiourea mixed solvent without microwave irradiation was verified as $81.4158 \%$. However, the maximum leaching percent at all samples irradiated by microwaves for $70 \mathrm{~min}$ was more than $100 \%$. The leaching rate constant, which was a rate parameter, was increased from 0.0561 to $0.0783 \mathrm{~min}^{-1}$ as the microwave irradiation time increased from $0 \mathrm{~min}$ to $70 \mathrm{~min}$. In particular, the temperature of the sample suddenly increased at the Experiment $\mathrm{E}$ condition, whose temperature was $850^{\circ} \mathrm{C}$ or higher. Elution efficiency of the gold depending on the amount of thiourea showed no significant change. However, the elution rate of gold increased with the amount of solvent added. For this reason, the enhancement of gold leachability was probably due to the increase in surface area as a result of pyrite oxidation and the formation of a porous hematite structure.

Table 3. The summary of leaching parameter for Au leaching test using Equation (1).

\begin{tabular}{cccc}
\hline Experiment & $\boldsymbol{E}_{\boldsymbol{I}} \mathbf{( \% )}$ & $\boldsymbol{k}\left(\mathbf{m i n}^{\mathbf{- 1}} \mathbf{)}\right.$ & $\mathbf{R}^{\mathbf{2}}$ \\
\hline A & 81.42 & 0.0561 & 0.9804 \\
B & 84.06 & 0.0601 & 0.9780 \\
C & 88.45 & 0.0612 & 0.9757 \\
D & 96.02 & 0.0624 & 0.9768 \\
E & 100.00 & 0.0783 & 0.9830 \\
F & 100.00 & 0.0837 & 0.9805 \\
G & 100.00 & 0.0901 & 0.9773 \\
\hline
\end{tabular}

The leaching rate constant increased according to the increase in the concentration of the thiourea mixed solvent, and the highest rate was $0.0901 \mathrm{~min}^{-1}$ at the Experiment $\mathrm{G}$ condition.

\section{Conclusions}

In this study, we investigated the effect of microwave pretreatment on the recovery of gold from gold concentrate by thiourea leaching. As the microwave irradiation time increased, the sample temperature increased and the total mass of the samples was reduced; in particular, the sulfur was significantly removed from the concentrates. The microwave treatment resulted in a mineral phase change from pyrite to hematite or pyrrhotite. The Au leaching experiment was conducted using a 
thiourea mixed solvent. The gold leaching from the concentrate could be significantly enhanced by the microwave pretreatment due to the microcracks that developed on the pyrite surface. The results of this study confirmed that the microwave irradiation could be used as an effective pretreatment process to enhance gold recovery in advance of the hydrometallurgy process.

Acknowledgments: This subject is supported by Korea Ministry of Environment (MOE) as "Advanced Technology Program for Environmental Industry" (Technologies for the Risk Assessment and Management 2016000140010).

Author Contributions: Nag-Choul Choi carried out the transport experiments, participated in the reference research, and drafted the manuscript. Bong-Ju Kim participated in the design of the study, and supervised the research work. Kanghee Cho carried out the model analysis. Soonjae Lee revised and edited the manuscript. Cheon-Young Park conceived of the study, participated in its design and coordination, and helped to draft the manuscript. All authors read and approved the manuscript.

Conflicts of Interest: The authors declare that they have no competing interests.

\section{References}

1. $\mathrm{Xu}$, B.; Yang, Y.; Li, Q.; Li, G.; Jiang, T. Fluidized roasting-stage leaching of a silver and gold bearing polymetallic sulfide concentrate. Hydrometallurgy 2014, 147, 79-82. [CrossRef]

2. Örgül, S.; Atalay, Ü. Reaction chemistry of gold leaching in thiourea solution for a turkish gold ore. Hydrometallurgy 2002, 67, 71-77. [CrossRef]

3. Aylmore, M.G.; Muir, D.M. Thermodynamic analysis of gold leaching by ammoniacal thiosulfate using $\mathrm{Eh} / \mathrm{pH}$ and speciation diagrams. Miner. Metall. Process. 2001, 18, 221-227.

4. Xu, B.; Yang, Y.; Li, Q.; Jiang, T.; Li, G. Stage leaching of a complex polymetallic sulfide concentrate: Focus on the extraction of Ag and Au. Hydrometallurgy 2016, 159, 87-94. [CrossRef]

5. Filmer, A. The dissolution of gold from roasted pyrite concentrates. J. S. Afr. Inst. Min. Metall. 1982, 82, 90-94.

6. Dunn, J.; Chamberlain, A. The recovery of gold from refractory arsenopyrite concentrates by pyrolysis-oxidation. Miner. Eng. 1997, 10, 919-928. [CrossRef]

7. Boyabat, N.; Özer, A.; Bayrakceken, S.; Gülaboğlu, M. Thermal decomposition of pyrite in the nitrogen atmosphere. Fuel Process. Technol. 2004, 85, 179-188. [CrossRef]

8. Ozkan, A.; Aydogan, S.; Akdemir, U. Bacterial leaching as a pre-treatment step for gold recovery from refractory ores. Fizykochem. Probl. Miner. 1998, 32, 173-181.

9. Pickles, C. Microwaves in extractive metallurgy: Part 2-A review of applications. Miner. Eng. 2009, 22, 1112-1118. [CrossRef]

10. Uslu, T.; Atalay, Ü. Microwave heating of coal for enhanced magnetic removal of pyrite. Fuel Process. Technol. 2004, 85, 21-29. [CrossRef]

11. Huang, J.; Rowson, N. Heating characteristics and decomposition of pyrite and marcasite in a microwave field. Miner. Eng. 2001, 14, 1113-1117. [CrossRef]

12. Ma, S.; Luo, W.; Mo, W.; Su, X.; Liu, P.; Yang, J. Removal of arsenic and sulfur from a refractory gold concentrate by microwave heating. Miner. Eng. 2010, 23, 61-63. [CrossRef]

13. Amankwah, R.; Khan, A.; Pickles, C.; Yen, W. Improved grindability and gold liberation by microwave pretreatment of a free-milling gold ore. Miner. Process. Extr. Metall. 2005, 114, 30-36. [CrossRef]

14. Kim, K.-J.; Ahn, H.-G. The effect of pore structure of zeolite on the adsorption of VOCs and their desorption properties by microwave heating. Microporous Mesoporous Mater. 2012, 152, 78-83. [CrossRef]

15. Haque, K.E. Microwave energy for mineral treatment processes-A brief review. Int. J. Miner. Process. 1999, 57, 1-24. [CrossRef]

16. Amankwah, R.; Ofori-Sarpong, G. Microwave heating of gold ores for enhanced grindability and cyanide amenability. Miner. Eng. 2011, 24, 541-544. [CrossRef]

17. Amankwah, R.; Pickles, C. Microwave roasting of a carbonaceous sulphidic gold concentrate. Miner. Eng. 2009, 22, 1095-1101. [CrossRef]

18. Zhang, Z.; Zhao, Z.K. Solid acid and microwave-assisted hydrolysis of cellulose in ionic liquid. Carbohydr. Res. 2009, 344, 2069-2072. [CrossRef] [PubMed] 
19. Pert, E.; Carmel, Y.; Birnboim, A.; Olorunyolemi, T.; Gershon, D.; Calame, J.; Lloyd, I.K.; Wilson, O.C. Temperature measurements during microwave processing: The significance of thermocouple effects. J. Am. Ceram. Soc. 2001, 84, 1981-1986. [CrossRef]

20. Menéndez, J.; Menéndez, E.; Garcia, A.; Parra, J.; Pis, J. Thermal treatment of active carbons: A comparison between microwave and electrical hating. J. Microw. Power Electromagn. Energy 1999, 34, 137-143. [CrossRef]

21. Robinson, J. The extraction of gold from sulphidic concentrates by roasting and cyanidation. J. S. Afr. Inst. Min. Metall. 1988, 88, 117-130.

22. Swash, P. A mineralogical investigation of refractory gold ores and their beneficiation, with special reference to arsenical ores. J. S. Afr. Inst. Min. Metall. 1988, 88, 173-180.

23. Aylmore, M.G. Treatment of a refractory gold-copper sulfide concentrate by copper ammoniacal thiosulfate leaching. Miner. Eng. 2001, 14, 615-637. [CrossRef]

24. Tanrıverdi, M.; Mordoğan, H.; İpekoğlu, Ü. Leaching of ovacık gold ore with cyanide, thiourea and thiosulphate. Miner. Eng. 2005, 18, 363-365. [CrossRef]

25. McLaughlin, J.; Agar, G. Development and application of a first order rate equation for modelling the dissolution of gold in cyanide solution. Miner. Eng. 1991, 4, 1305-1314. [CrossRef]

26. McGill, S.; Walkiewicz, J.W.; Clark, A. Microwave Heating of Chemicals and Minerals; US Department of the Interior, Bureau of Mines: Washington, DC, USA, 1995.

27. Salsman, J.; Williamson, R.; Tolley, W.; Rice, D. Short-pulse microwave treatment of disseminated sulfide ores. Miner. Eng. 1996, 9, 43-54. [CrossRef]

28. Uslu, T.; Atalay, Ü.; Arol, A. Effect of microwave heating on magnetic separation of pyrite. Colloids Surf. A Physicochem. Eng. Asp. 2003, 225, 161-167. [CrossRef]

29. Ling, H. Study on waste liquid return process in bacterial oxidation of low-sulfur hard-handle gold concentrates. Mod. Min. 2013, 2, 009.

30. Vaughan, D.J.; Craig, J.R. The crystal chemistry of iron-nickel thiospinels. Am. Mineral. 1985, 70, $1036-1043$.

31. Hwang, J.-Y.; Shi, S.; Xu, Z.; Huang, X. Oxygenated leaching of copper sulfide mineral under microwave-hydrothermal conditions. J. Miner. Mater. Charact. Eng. 2002, 1, 111. [CrossRef]

32. Vorster, W.; Rowson, N.; Kingman, S. The effect of microwave radiation upon the processing of neves corvo copper ore. Int. J. Miner. Process. 2001, 63, 29-44. [CrossRef]

33. Olubambi, P.; Potgieter, J.; Hwang, J.; Ndlovu, S. Influence of microwave heating on the processing and dissolution behaviour of low-grade complex sulphide ores. Hydrometallurgy 2007, 89, 127-135. [CrossRef]

34. Wang, G.; Radziszewski, P.; Ouellet, J. Particle modeling simulation of thermal effects on ore breakage. Comput. Mater. Sci. 2008, 43, 892-901. [CrossRef]

35. Wang, Y.; Djordjevic, N. Thermal stress FEM analysis of rock with microwave energy. Int. J. Miner. Process. 2014, 130, 74-81. [CrossRef]

36. Beeby, J.P. The Recovery of a Valuable Species from an Ore. Google Patents WO 1,992,018,249 A1, 29 October 1992.

37. Kingman, S.; Vorster, W.; Rowson, N. The influence of mineralogy on microwave assisted grinding. Miner. Eng. 2000, 13, 313-327. [CrossRef]

38. Kingman, S.; Jackson, K.; Bradshaw, S.; Rowson, N.; Greenwood, R. An investigation into the influence of microwave treatment on mineral ore comminution. Powder Technol. 2004, 146, 176-184. [CrossRef]

(c) 2017 by the authors. Licensee MDPI, Basel, Switzerland. This article is an open access article distributed under the terms and conditions of the Creative Commons Attribution (CC BY) license (http://creativecommons.org/licenses/by/4.0/). 